https://helda.helsinki.fi

\title{
Demonstratives as spatial deictics or something more? Evidence from Common Estonian and Võro
}

\section{Reile, Maria}

2020-04

Reile , M , Plado , H , Gudde , H B \& Coventry , K R 2020 , ' Demonstratives as spatial deictics or something more? Evidence from Common Estonian and Võro ' , Folia Linguistica , vol. 54 , no. 1 , pp. 167-195 . https://doi.org/10.1515/flin-2020-2030

http://hdl.handle.net/10138/329141

https://doi.org/10.1515/flin-2020-2030

publishedVersion

Downloaded from Helda, University of Helsinki institutional repository.

This is an electronic reprint of the original article.

This reprint may differ from the original in pagination and typographic detail.

Please cite the original version. 


\section{Maria Reile*, Helen Plado, Harmen B. Gudde and Kenny R. Coventry \\ Demonstratives as spatial deictics or something more? Evidence from Common Estonian and Võro}

https://doi.org/10.1515/flin-2020-2030

Submitted July 03, 2018; Revision invited November 28, 2018;

Revision received July 31, 2019; Accepted August 14, 2019

Abstract: There is debate regarding the extent to which egocentric distance versus a more interactional approach underpin the use of spatial demonstratives across languages. This study experimentally tested the influence of object distance from a speaker and two dynamic speech-situation related parameters position of an interlocutor, and the one who placed the object referred to - on adnominal demonstrative pronoun choice in two very close kindred languages: Estonian and Võro. These languages are spoken in the same geographical region and are closely related yet have different demonstrative systems. Our results confirmed the influence of egocentric distance on the choice of adnominal demonstrative pronouns in both languages, but the influence of two more interactional factors was found only in Võro. These results highlight the importance of egocentric distance underlying the use of demonstratives in a spatial context but also show that languages that are even closely related vary in the extent to which additional parameters affect dedmonstrative choice.

Keywords: deictic reference, exophoric demonstratives, two and three-term systems, experimental method, Finno-Ugric languages

*Corresponding author: Maria Reile, Institute of Estonian and General Linguistics, University of Tartu, Jakobi 2 Tartu, Estonia, E-mail: maria.reile@ut.ee

https://orcid.org/0000-0003-1786-9426

Helen Plado, Department of Finnish, Finno-Ugrian and Scandinavian Studies, University of Helsinki, Finland; Institute of Estonian and General Linguistics, University of Tartu, Jakobi, Tartu, Estonia, E-mail: helen.plado@helsinki.fi

Harmen B. Gudde, University of East Anglia, Norwich, England; Hanse-Wissenschaftskolleg Institute for Advanced Study, Delmenhorst, Germany, E-mail: h.gudde@uea.ac.uk

Kenny R. Coventry, University of East Anglia, Norwich, England, E-mail: k.coventry@uea.ac.uk 


\section{Introduction}

Demonstratives are one of the core elements of communication since they can be used to draw the attention of a hearer to referents in surrounding space and to create a joint focus of attention (Diessel 2006). While the use of demonstratives can be classified in several ways (e.g. Lyons 1977; Himmelmann 1996; Diessel 1999; Levinson 2006; Talmy 2018), the most common distinction made is between endophoric or exophoric reference (Halliday and Hasan 1976). Demonstratives in endophoric reference are used to refer to the referents within the discourse; in exophoric reference demonstratives are used to indicate concrete physical entities in space.

In studies focusing on the exophoric use of demonstratives, there are two equally plausible approaches to factors that have an effect on demonstrative use. First, the distance-based approach, in which the choice and use of spatial demonstratives is influenced by the relative distance of the referent from the interlocutors (e. g. Lyons 1977; Fillmore 1997). This approach has strong typological and empirical support (Diessel 1999, 2013; Dixon 2003). Second, an interaction-based approach, which emphasises the dynamicity of exophoric demonstrative use and argues that the simple near-far distinction is not enough to explain their use in various contexts (e.g. Hanks 1992; Laury 1997; Enfield 2003). Moreover, some authors arguing for more interaction-based 'sociocentric' approaches to demonstratives have suggested that, in face-to-face interaction, distance from a speaker does not affect demonstrative choice, but instead the proximal term is used to refer to any position in shared space (Peeters et al. 2015; Peeters and Özyürek 2016).

In the distance-based approach, demonstratives are thought to be used primarily egocentrically (Lyons 1977; Fillmore 1997). That is, the "spatiotemporal zero-point [the origo] is determined by the place of the speaker at the moment of utterance" (Lyons 1977: 638). The speaker relates everything to his/her viewpoint, and demonstratives in English could be interpreted to refer to a referent that is near (this, here) or far (that, there) from the speaker. In line with this distance-based approach, typological studies have proposed that many (if not all) of the world's languages have at least two demonstratives (which may be demonstrative pronouns, adverbs or particles) that are assumed to convey distance contrasts (Diessel 1999, 2013; Dixon 2003). Based on adnominal demonstratives (demonstrative pronouns used with an accompanying NP), Diessel (2013) suggests that most languages have demonstrative pronoun systems with a two-way contrast, differentiating between near and far, like for example English. Demonstrative pronoun systems in languages that have a three-way 
contrast, such as Japanese, could contrast more parameters, for example distance and/or the position of an interlocutor (Anderson and Keenan 1985; Diessel 1999). More recent studies have shown that the proximal and distal terms can be anchored to either the speaker, the hearer, or both (Levinson 2018: 19), consistent with the view that the deictic centre can shift (see Diessel 2014 for discussion).

Empirical research on demonstrative use has shown a possible connection between demonstrative use and the distinction between peripersonal and extrapersonal space (Caldano and Coventry 2019; Coventry et al. 2008, 2014; Gudde et al. 2016). In neuropsychology, there is evidence that different brain regions are associated with processing of peri- and extrapersonal space (di Pellegrino and Làdavas 2015). Peripersonal space is defined as space within our reach - objects in peripersonal space can be grasped and manipulated; extrapersonal space lies beyond this grasping distance. It has been shown that manipulating tool use extends the perception of peripersonal space (Berti and Frassinetti 2000) and correspondingly also extends the use of English and Spanish proximal demonstrative pronouns (Coventry et al. 2008). Recently Caldano and Coventry (2019) have also shown that this is used more to describe the location on the lateral axis if the hand used to point at that location can reach it irrespective of whether the hand pointing is one's preferred or dispreferred hand. In addition, several studies now show a graded change in demonstrative choice in English on the border between peripersonal and extrapersonal change, consistent with neurospsychological findings (Coventry et al. 2014; Gudde et al. 2016).

An alternative view of the use of demonstratives is that their use has to do with the social and interactional factors of the speech event (e.g. Hanks 1992, Hanks 2009, Hanks 2011; Laury 1997; Enfield 2003; Etelämäki 2009). According to Bohnemeyer (2012: 100) the interactional parameters include "participants, their locations in real and in social space, and the location of the reference object (or 'denotatum') in these co-ordinate systems". For example, Laury (1997: 58-59) argues, based on Hanks (1992: 66), that demonstratives in Finnish (a three-term system) convey social and cognitive accessibility rather than concrete distance of the object referred to from the interlocutors. Nevertheless, Laury (1997: 59) also states that it is possible for these parameters to overlap with distance of the referred object. According to this approach tämä (roughly equivalent to this) indicates that the referent belongs to the speaker's sphere; se (the term of Finnish, which in person-oriented approaches denotes that the referent is near the hearer [Larjavaara 1990]) indicates that the referent belongs to the hearer's sphere; and tuo (roughly equivalent to that) shows that the referent does not belong to either of the spheres. In other words, tämä and se are 
inclusive and tuo an exclusive demonstrative pronoun indicating the relation that the speaker and the addressee have to the object referred to. While in this approach, the focus is not as much on the physical aspects of reference but rather on social and cognitive factors, this notion of access can be transferred to physical manipulation of objects in one's peripersonal space. The objects manipulated in one's peripersonal space can be perceived as closer and therefore more accessible to the speaker than when referred objects have previously been in someone else's peripersonal space (Coventry et al. 2008).

Another aspect of an interactional setting that can influence the use of demonstratives is the viewpoint of the interlocutors to the object referred to. In other words, the location of the interlocutors and the objects referred to in an interactional space. For example, Jungbluth (2003) claims that the position of the interlocutors, whether they are situated face-to-face or next to one another, can have an effect on the use of proximal demonstrative pronoun in Spanish, experimentally confirmed by Coventry et al. (2008). The face-to-face position, which Jungbluth (2003: 27) calls a conversational dyad, "stretches" the scope of use of the proximal demonstrative pronoun (the distance in which the proximal term is used) compared to the situations where the interlocutors are situated next to one another, sharing a mutual viewpoint to the referent. Therefore, the scope of conversational dyad is defined by the addressee. Peeters et al. (2015), using electroenceohalography, report evidence that face-to-face interaction is associated with an expectation that this will be used to describe the location of an object at any distance between speaker and hearer when they are in an interactional communicative context.

In addition to position of the interlocutors, several studies propose that also other interactional factors, such as joint attention (Enfield 2003; Küntay and Özyürek 2006; Diessel 2006; Jarbou 2010; Peeters et al. 2015), and the object's possession/ownership by one of the interlocutors (Bohnemeyer 2012; Coventry et al. 2014), affect demonstrative use. Indeed it has been argued that distance is only one of the possible parameters that may have an influence on demonstrative use, other parameters, such as perception, prior talk and memory, may also play a role (Hanks 2011; Coventry et al. 2014).

There appears to be a variety of factors that affect the use of demonstrative pronouns in different languages, and it is as yet unclear whether an explicitly marked contrast in one language is also contrasted in another language. For example, cognitive accessibility is suggested to be relevant in the choice of Dutch demonstrative pronouns (Piwek et al. 2008) but does not seem to have an effect on the choice of Hungarian demonstrative pronouns (Tóth et al. 2014) in exphoric reference. At the same time, the influential factors that are explicitly expressed in one language, for example if a certain demonstrative pronoun 
indicates visibility of the referent (Diessel 1999) this can also affect demonstrative use in languages that do not explicitly contrast this aspect (Coventry et al. 2014). Levinson (2018: 24) suggests, for instance, on the basis of empirical studies in multiple languages, that there is a possibility that the 'medial' terms in languages with three-term distance-oriented systems are not true medials but rather spatially unmarked forms which cover the areas that the terms with clear distance codings, i. e. proximals and distals, cannot be used for. In addition, Coventry et al. (2014) have shown empirically that distance and other parameters, such as object ownership, familiarity and visibility, affect demonstrative choice in English even though these contrasts are not explicitly marked in English. This shows that demonstrative systems are more complex than previously thought and that there are multiple factors alongside distance that may have an effect on demonstrative use.

While in recent years there has been a debate over which of the factors are primary to demonstrative choice, distance- or interaction-dependent factors (cf. Hanks 2011), only a few studies have tested both the influence of distance and interactional parameters on demonstrative choice simultaneously (Coventry et al. 2008, 2014; Peeters et al. 2015). Moreover, demonstrative studies using experimental methods are carried out mostly in Indo-European languages, such as English and Spanish, while the great variety in which languages carve up space makes it important to study languages across language families (Evans and Levinson 2009). In addition, it is necessary to use different research methods, both experimental and observational, to get a better insight into demonstrative use (Bohnemeyer 2012).

In this study, we focus on an explicitly spatial situation where we manipulate factors in interactional space. The main objective of this study is to test, using experimentally controlled conditions, whether the distance of the referent from the interlocutors and two interactional space parameters: speaker's interaction with the object referred to and the position of a hearer during the experiment, have an effect on demonstrative use in two closely related Finno-Ugric languages which have different demonstrative pronoun systems. To test these parameters, we used the established 'memory game' paradigm (Caldano and Coventry 2019; Coventry et al. 2008, Coventry et al. 2014; Gudde et al. 2016). This method (see Gudde et al. 2018 for visualised procedure) affords experimental control over parameters under investigation, critically without speakers being aware that their language is being tested. Therefore, the procedure provides experimental control of natural language use. The design of the experiment also enabled us to keep the speech-situation purely exophoric (single reference to one object at a time). The main goal was to test the influence of distance from speaker, addressee position, and the one who places an object, on 
demonstrative choice in two languages. Critically, the manipulation of addressee position affords testing the claim that demonstratives in a face-to-face situation sets up a shared space which should licence the use of the proximal term irrespective of the distance of an object from the speaker (Peeters et al. 2015, Peeters et al. 2016) as compared with the view that a mapping between distance and demonstratives is primary (albeit with the possibility of shifts in deictic centre: Coventry et al. 2008, Coventry et al. 2014; Diessel 2014). To preview the results, we show that distance has an influence on the choice of demonstrative pronouns in both languages, but the parameters connected to interactional space seem to be more language specific, and when they are present they do not replace distance contrasts but are additional to them.

\section{Estonian and Võro demonstratives}

\subsection{Estonian and Võro as Finno-Ugric languages}

Estonian and Võro belong to the Finnic branch of Finno-Ugric languages (Uralic language family). Historically, Southern Estonian, which includes Võro, was the first language to diverge from other Finnic languages. Estonian, the official language of Estonia, diverged from the Finnic languages later (Sammallahti 1977; Kallio 2007: 243). Both languages are descendants of Proto-Baltic-Finnic.

The number of Estonian and Võro language speakers is relatively small. According to the 2011 Population and Housing Census (Statistics Estonia 2012), there are 886,859 Estonian and 87,048 potential ${ }^{1}$ Võro speakers in Estonia. It is important to note that there are no monolingual Võro speakers left. All Võro speakers are bilingual, speaking both Võro and (Common) Estonian. The most recent research on the use of Võro was conducted during the project European Language Diversity for All $\left(\right.$ ELDIA $\left.^{2}\right)$. The results demonstrated clearly that bilingualism inherently belongs to the everyday life of Võro speakers. Võro is most often used with grandparents and in private informal settings. However, there is no domain where Võro is used exclusively. Only around one quarter of the participants of the ELDIA study claimed to always use Võro at home. In line

1 In the 2011 Population and Housing Census, people who have marked Estonian as their mother tongue, have been asked "Do you speak some local language form, dialect, or subdialect?" People have defined themselves whether they speak Võro language or not, but the language proficiency level differs between the respondents (see also Jääts 2015 for discussion). 2 https://www.eldia-project.org/. 
with using Võro mostly in private situations, Võro is used less in formal situations, such as in church, at school, and with public authorities (Koreinik 2013: 63, 70-72). Due to intensive language contact, Võro is strongly influenced by Common Estonian, and in modern Võro one can observe Estonian features throughout the language.

Võro has never been the medium of instruction in schools. Native Võro speakers have been educated in Estonian for the last hundred years. Võro has been taught in schools as a subject only since the 1990s. The first Vorro classes were taught in 1994 in two schools in the Vorro language region. ${ }^{3}$ Although the number of the schools where Võro is taught has increased since the 1990s, Võro is taught only in some grades in less than half of all the schools in the language region (in 12 schools out of 34).

Although the Estonian Language Act (2011) regards Võro officially as a regional variety of Estonian, there are significant differences between the languages. Based on the features of articulation and morphology as well as on basic vocabulary of Saareste's (1955) dialectal maps, Pajusalu (1997) has calculated that Võro and Standard Estonian only overlap in the region of $18.7 \%$. For example, unlike Estonian, Võro has vowel harmony and certain phonemes that Estonian lacks. Võro morphology is more fusional (Pajusalu et al. 2009), there are differences in case forms and syntax (for example in the voice system, agreement, and negation), and there is a non-common basic vocabulary. In addition, and most critically, while both languages are descendants of ProtoBaltic-Finnic - a language which had four demonstrative stems: *tämä, ${ }^{\star} t a a$, ${ }^{\star} t \bar{o}$, ${ }^{\star}$ se (Larjavaara 1986) - Common Estonian has two and Võro has three demonstrative pronouns. Thus, one of the languages has lost more counterparts than the other in the course of time.

Taking all of the above in consideration and despite the fact that Vorro is often seen as a dialect of Estonian, we here treat it as a distinct language. The decision is also based on the criterion of mutual intelligibility (not all Common Estonian speakers understand Võro) as well as language political factors (e. g. the increasing recognition of Võro as a language).

\subsection{Estonian demonstrative pronoun systems}

There are at least two demonstrative pronoun systems within Common Estonian. Mostly in South-Eastern parts of Estonia (Figure 1) two demonstrative pronouns, see and too are used; in other areas, only see is used (Pajusalu 2009). Thus,

3 https://wi.ee/tegemise/koolioppus/. 


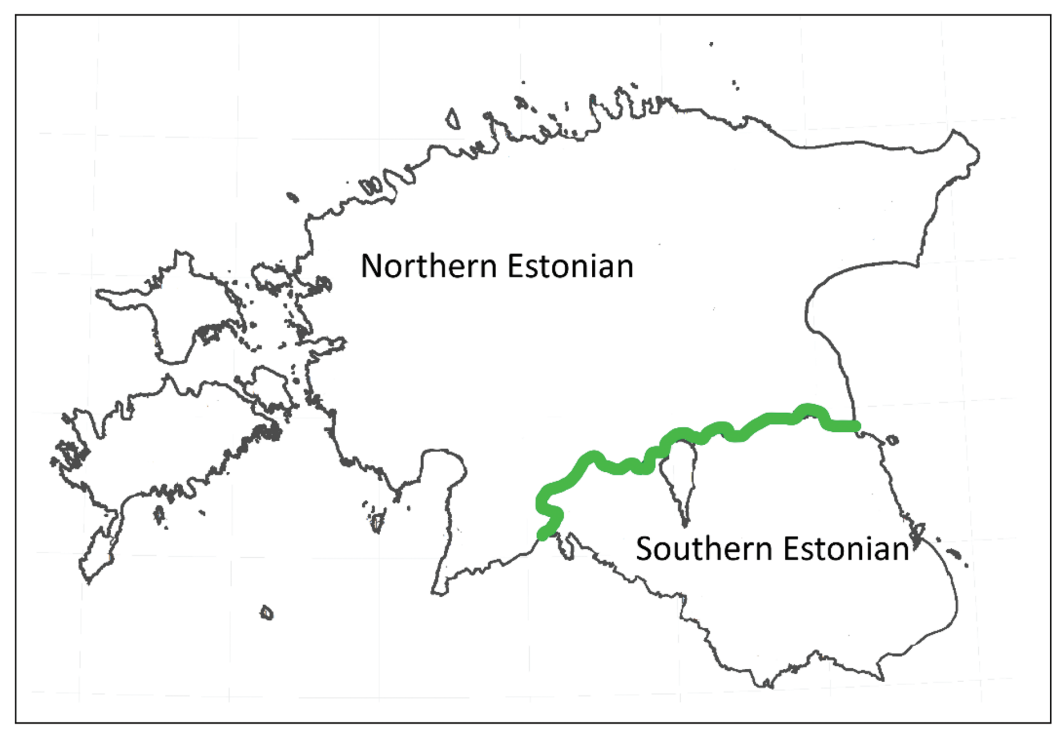

Figure 1: The regions of Northern and Southern Estonian dialects (the green line denotes the division) where one-term and two-term systems are used respectively. (Adapted from the Dialectological Dictionary of Estonian).

there is a two-term demonstrative pronoun system consisting of see and too, and a one-term demonstrative pronoun system with only see. The region of use of these demonstrative pronoun systems overlaps with the historical dialect division of Estonian. The one-term system is used in the region of the Northern Estonian dialect and the two-term system in the region of the Southern Estonian dialect (Figure 1) (Pajusalu et al. 2018).

Previous studies focusing on exophoric use of Estonian demonstratives have shown that in the one-term system, see is used to refer to any referent regardless of its distance from the speaker and thus is distance neutral (Larjavaara 2007; Pajusalu 2009; Reile 2015). To indicate distance of the referent, distal and proximal demonstrative adverbs are added to see in a referential act (Reile 2015). For example, by adding the proximal demonstrative adverb siin 'here' to the demonstrative pronoun see, the referential phrase denotes an entity that is situated near the speaker, e. g. see siin 'this (one over) here'.

In the two-term system, see indicates referents that are close to the speaker, yet it is said to convey the indication of proximity only in the context where it is used contrastively with too (otherwise, see is used in the same way as in the oneterm demonstrative pronoun system) (Pajusalu 2009). A previous study (Reile 2016) has shown that too is rarely used for proximal referents and that it 
combines with distal demonstrative adverbs rather than proximals. Thus the scope of use of see is much wider than the scope of too; this differs from the use of the corresponding items in, for example, English and Hungarian (Strauss 2002; Tóth et al. 2014) where the use of the distal demonstrative pronoun is more frequent than the use of the proximal one.

In endophoric use, see has more diverse functions than too. For example, see can be used to denote any referent (Pajusalu 2017), including reference to on-going time or previously mentioned time (Pajusalu 1997a) provided that the referent is at least activated. See can function also as a definite determiner (Pajusalu 1997b) and a hesitation marker (Keevallik 2010). Too, however, is almost never used as a definite determiner in Standard Estonian (Hint et al. 2017) and it is mostly used to refer to past time and secondary characters in literary narratives (Pajusalu 2006).

While previous studies on exophoric use indicate the importance of distance in the choice of Estonian demonstrative pronouns, only one of the studies mentioned above (Reile 2016) used an experimental method to test the distance influence on the two-term demonstrative system, providing comparative data for other languages. Furthermore, the possible influence of interactional parameters, such as position of the interlocutors or the speaker's interaction with the object referred to, has not yet been tested.

\subsection{Võro demonstrative pronoun system}

In Võro language, there are three demonstrative pronouns: sjoo, taa, and tuu. The region of use of this three-term demonstrative pronoun system coincides with the region where the Common Estonian two-term system is used (Figure 2).

There have been two approaches in explaining the Võro demonstrative system in exophoric use: it has been thought to consist of (1) speaker-anchored terms (Keem and Käsi 2002: 44) or (2) speaker- and addressee-anchored terms (Pajusalu 1998). In the first approach, the terms indicate different degrees of distance of the objects only from the speaker. In contrast, the second approach proposes that sjoo is used to refer to the referents near the speaker, taa to referents near the hearer and tuu to referents far from both speaker and hearer (Pajusalu 1998, Pajusalu 2009). In addition, Pajusalu (2015) has suggested, on the basis of a video-based corpus study, that the Vorro system is changing and has lost its addressee-anchored use of the middle term taa. Pajusalu (2015) also proposes that the difference between taa and tuu use is that the entities referred to with tuu do not have to be in anyone's sphere at the moment of utterance, while with taa, the referent is present for the speaker as well as for the addressee. For sjoo use, a gesture is added to the referential act, while when using taa, the speaker quite often does not use a gesture. 


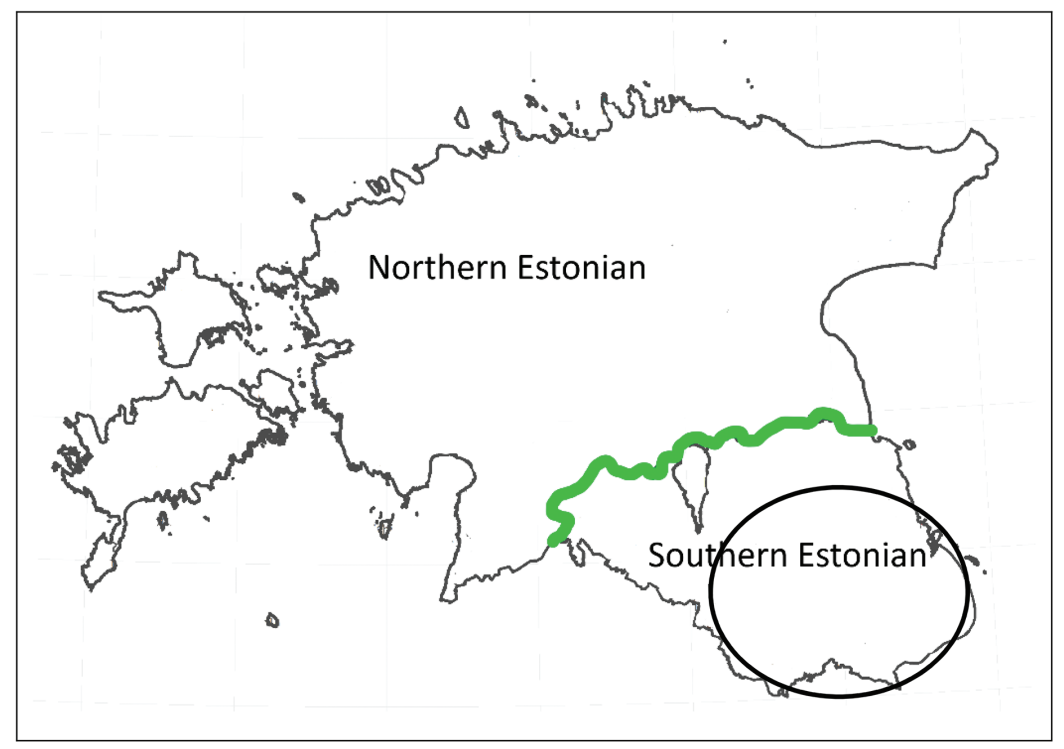

Figure 2: The region of use of the Võro three term system in Estonia (denoted by the circle).

In endophoric reference, the most productive demonstrative pronoun is tuu. It is used to refer to previously described events or propositions and also to abstract, animate and inanimate referents (Pajusalu 1998; Tammekänd 2015). Furthermore, tuu is used exclusively to refer to persons (Pajusalu 2015). In addition, it also functions as a determiner and has an article-like usage. The least prototypical pronoun in endophoric reference is sjoo. While this demonstrative can be used to refer to inanimate referents, it functions rather as a discourse deictic. Similarly to sjoo, taa is used infrequently in written text and it seems to be used mainly in referring to units of texts, such as propositions, narratives and opinions rather than concrete referents (Pajusalu 2015). In addition, a study of demonstrative pronoun use in narrative context has shown that this three-term system seems to be disintegrating into different systems since not all of the participants used all three demonstrative pronouns (Tammekänd 2015).

This different proposed classifications of the Võro exophoric demonstrative pronoun system shows that there is as yet no clear consensus on how Vorro demonstratives function. In addition, the constant influence of Estonian oneand two-term systems may have caused changes in the Voro three-term system. Moreover, none of the aforementioned studies used experimental methods in their research, making it quite difficult to compare the Võro system to Estonian systems. 
As we have seen above, despite very close historical and cultural relations between Võro and Estonian, and the fact that one is sometimes classified as a dialect of the other, there are striking differences between the languages including their demonstrative pronoun systems. While there are two demonstrative pronouns in Estonian, Võro has three, in which taa does not have a demonstrative counterpart in Estonian. Another important aspect of these systems is that both of them are used approximately in the same region of Estonia and therefore continuously influence one another. Thus, we have two very similar languages, spoken in the same territory within the same socio-cultural environment, but still showing differences in something as fundamental as the demonstrative pronoun system.

\section{Method}

We conducted an experiment using the established 'memory game method' (originally developed by Coventry et al. 2008) with minor adjustments to test Common Estonian and Võro. The memory game procedure is carefully experimentally controlled to test language use without participants being aware that their language is being tested (Coventry et al. 2008; see also Gudde et al. 2018). In the procedure, participants are seated at a long conference table on which locations are colour coded and situated on a line along the middle of the table. To prevent participants from knowing that the study tests language, they are told that they are participating in a study that tests for the influence of language on memory and that they are in a (supposed) language condition. This means that on every trial, when an object is placed at one of the locations, they are asked to encode this in memory using language. To make this similar for all participants, they are instructed to use just three words: [demonstrative], [colour of object], [name of object] (e. g. "this red circle") while pointing at the placed object. The experimenter notes the demonstrative used, and then proceeds with the next trial. To maintain the cover story, participants are asked what the most recent location of a few of the objects is at random intervals throughout the placement trials (Coventry et al. 2008, Coventry et al. 2014; Gudde et al. 2018). In the present version of the memory game, we manipulated the agent (who places the object [experimenter/ participant]), the object's distance from the participant, and the position of the experimenter (seated next to or opposite the participant).

Previous research has shown that demonstrative use is affected by interaction with an object; in English, when a participant places an object, the use of this is higher than when the experimenter places the object. Including this parameter allows us to test whether this is the same in Estonian and Võro, and if so, whether the effect size is variable across languages. We used 6 locations divided over 3 spaces 
(at 25, $50 \mathrm{~cm} ; 150,175 \mathrm{~cm} ; 275,300 \mathrm{~cm}$ ). The two locations in the first space are all within the peripersonal space of the participant, whereas the other two spaces are in extrapersonal space. However, when the experimenter is seated opposite the participant, the locations in space $3(275,300 \mathrm{~cm}$ from the participant) are in the peripersonal space of the experimenter. This enables testing between different theoretical functions of demonstratives, and more specifically the 'sociocentric' view of Peeters et al. $(2015,2016)$ that effects of distance should only occur when speaker and addressee are seated side-by-side and not when they are seated face-to-face.

\subsection{Participants}

Due to the language specifics in Common Estonian and Võro (see Section 2), we recorded, upon debriefing, demographic information (age, place of birth and use of dialects by their parents and the participants themselves), whether participants reported using all demonstratives in everyday life/communication, and what in their opinion the different meanings of the demonstratives are. In addition, we asked the participants what they thought the hypotheses for the experiment were, in order to ensure participants did not realise we were testing language.

The criteria for the participants were as follows: In the Common Estonian experiment we looked for native speakers of Estonian from Southern regions of Estonia where the demonstrative too is used in addition to see. In the Vorro experiment, we included only the native Võro speakers who had been using Võro since early childhood and who had been living in the Võro language area for most of their lives to ensure that their proficiency in Võro would not have declined. In addition, in both experiments, we included only participants who had not guessed the purpose of the experiment. Thus we could be sure that the use of demonstratives is natural and not influenced by demand characteristics or by participants thinking explicitly about how they use specific words.

Based on the aforementioned selection criteria, 32 participants (26 of whom were female, aged: $18-54, M=27.5, S D=10.1$ ) out of 43 in the Common Estonian experiment were included. Twenty-two of these were students from the University of Tartu and ten were residents of the Southern region of Estonia. From the eleven excluded participants, eight stated that they do not use too, one of the participants was able to reproduce all hypotheses, and one participant used a strategy to produce demonstratives (using too for objects placed by the experimenter and see for the other trials, a strategy to align with experimental instructions to try and use both demonstratives - if not for the instructions he would have used only see).

In the Võro experiment, we included data from 27 participants (14 of whom female, aged 22-70, $M=49.2, S D=12.5$ ) out of 36 , all residents of the Southern 
region of Estonia. Of the nine excluded participants four had not acquired Vorro as a child, four participants did not follow the instructions of the experiment and needed to be reminded which of the linguistic means to use, and one participant found the experimental task too hard and did not finish the experiment.

Participants in both experiments received course credits or a chocolate bar for their participation.

\subsection{Materials}

Six different coloured shapes were used in the experiment: a green star, red triangle, black cross, blue square, orange crescent and yellow heart (Figure 4). On each trial, one object was placed at one of six locations (out of 12 locations placed equidistantly from the participants' edge of the table). These six locations were chosen to locate objects within participants' reach (at 25 and $50 \mathrm{~cm}$ ), out of reach $(150,175 \mathrm{~cm})$, and furthest away on the other side of the table $(275,300 \mathrm{~cm})$ from the participant. Note that these latter two locations would be in the peripersonal space of the experimenter when seated opposite the participant. The experimenter instructed the placement of one of the objects on one of the locations (for example: Mina panen punase kolmnurga sinise täpi peale/Maq panõ verevä kolmnuka sinidse tsõõri pääle 'I place the red triangle on the blue dot').

\subsection{Design and procedure}

We manipulated the distance of the object (placed at 6 different locations, ${ }^{4}$ Figure 3 ), position of the experimenter, and the one who placed the object. The position condition was blocked (and counterbalanced); for one half of the experiment the experimenter was seated next to, and for the other half opposite, the participant. Location and object were pseudo-randomised and counterbalanced, such that no object or location was used in two successive trials. For both experiments, four different randomised trial lists were created.

The participant and experimenter were seated at a large table (at the narrow edge), covered with a black cloth. On every trial, one object was placed on one of the locations. The experimenter read from instruction cards who would places the object on each trial at which location. After the object was placed, the agent (experimenter or participant) returned to their initial position. Then the participant

4 There was an additional subset of trials in the procedure which we did not include in the current analysis, since the distances tested in the procedure were not matched across languages and are not part of the main scope of this paper. 


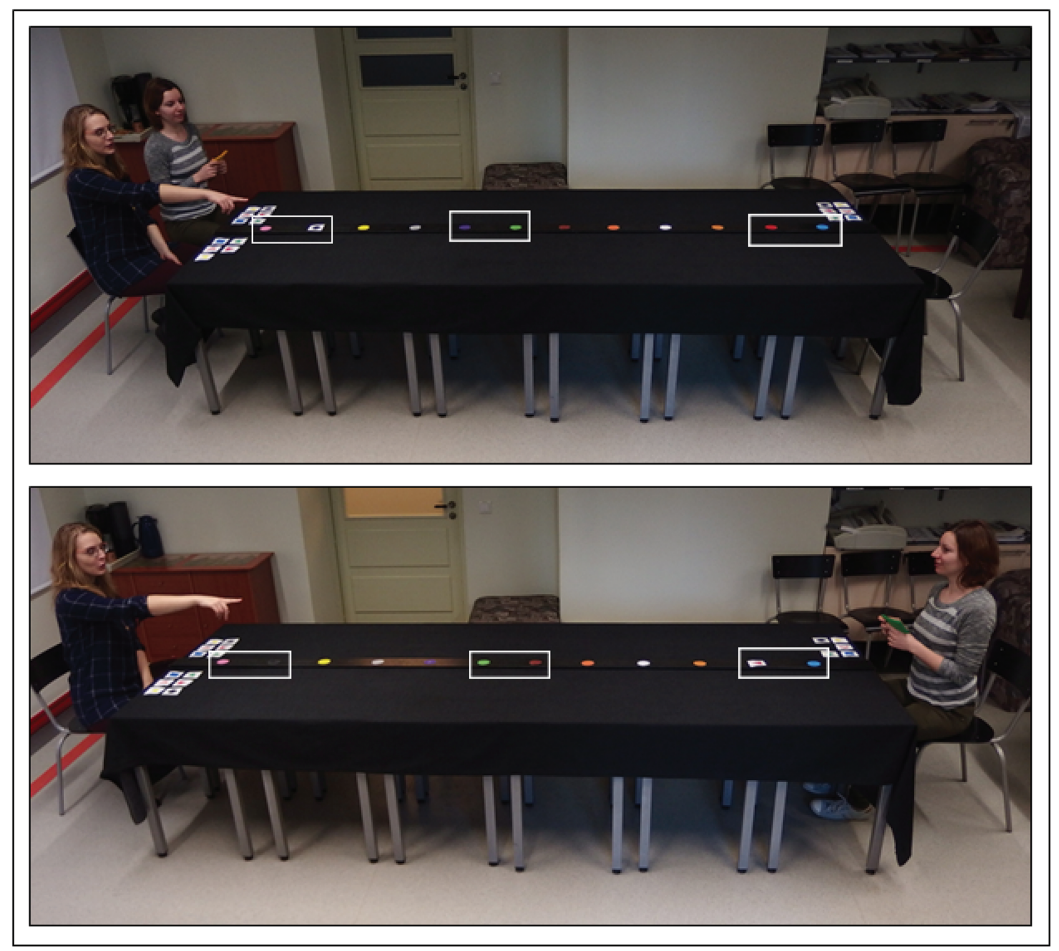

Figure 3: Set-up of the experiment. Upper panel: experimenter (holding instruction cards) and participant sitting side-by-side; Lower panel: experimenter and participant sitting opposite each other.
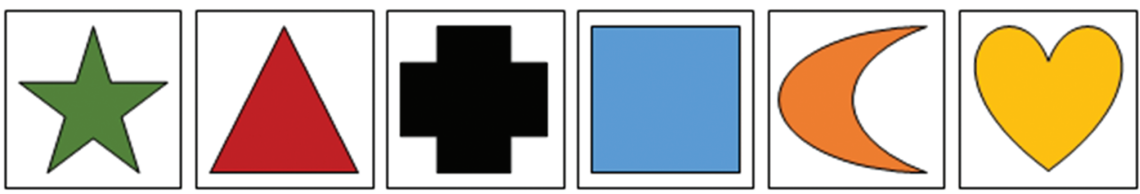

Figure 4: Shapes used in the experiments.

was asked to memorise the location of that object, while encoding it using language. The participant pointed at the object (without touching it), and named the object using three words: demonstrative, the colour of the object, and the object name. For example, in the Common Estonian experiment see/too punane kolmnurk, and in the Vorro experiment sjoo/taa/tuu verrev kolmnukk 'this/that red triangle' were used. It was explained that this made the verbal encoding as similar as 
possible for all participants, ensuring participants were unaware that their demonstrative choice was being tested. Next, the experimenter removed the object and proceeded with the next trial. After half of the trials, the experimenter changed her position (switching opposite to or next to the participant). To strengthen the memory cover-up, participants were asked four times during the placement trials to name the last four objects and their locations. There were six practice trials before the experimental trials, one trial per location. As the experimenters were native speakers of the tested languages, all conversation (including instructions) took place in the corresponding language (i. e. either in Võro or in Estonian).

There were 72 trials overall in both experiments. We had 3 repetitions for each cell of the 6 (location) $\times 2$ (agent) $\times 2$ (position) within-subject design. For the data analysis we used repeated measures ANOVAs.

\section{Results and discussion}

\subsection{Common Estonian experiment: Demonstratives in a 2-term system}

\subsubsection{Results}

Table 1 presents the overall mean percentage use of Estonian demonstratives by condition. As can be seen, too was used while referring to objects in extra- rather than peripersonal space in all conditions; the opposite was the case with see, although it should be noted that see could be used more in the farthest locations than too in the nearest locations.

Table 1: Frequencies of demonstrative use by agent, position and location.

\begin{tabular}{lllrrrrrr}
\hline Agent & Position & Demonstrative & $\mathbf{2 5} \mathbf{c m}$ & $\mathbf{5 0} \mathbf{c m}$ & $\mathbf{1 5 0} \mathbf{c m}$ & $\mathbf{1 7 5} \mathbf{c m}$ & $\mathbf{2 7 5} \mathbf{c m}$ & $\mathbf{3 0 0} \mathbf{c m}$ \\
\hline Experimenter & \multirow{2}{*}{ Next to } & see & $84.37 \%$ & $91.67 \%$ & $42.71 \%$ & $38.54 \%$ & $23.96 \%$ & $18.75 \%$ \\
& & too & $15.63 \%$ & $8.33 \%$ & $57.29 \%$ & $61.46 \%$ & $76.04 \%$ & $81.25 \%$ \\
& \multirow{2}{*}{ Opposite } & see & $84.37 \%$ & $85.42 \%$ & $44.79 \%$ & $23.96 \%$ & $16.67 \%$ & $11.46 \%$ \\
& & too & $15.63 \%$ & $14.58 \%$ & $55.21 \%$ & $76.04 \%$ & $83.33 \%$ & $88.54 \%$ \\
Participant & \multirow{2}{*}{ Next to } & see & $91.67 \%$ & $90.62 \%$ & $58.33 \%$ & $39.58 \%$ & $19.79 \%$ & $23.96 \%$ \\
& \multirow{3}{*}{ Opposite } & too & $8.33 \%$ & $9.38 \%$ & $41.67 \%$ & $60.42 \%$ & $80.21 \%$ & $76.04 \%$ \\
& & too & $91.67 \%$ & $90.62 \%$ & $52.08 \%$ & $38.54 \%$ & $23.96 \%$ & $18.75 \%$ \\
& & $8.33 \%$ & $9.38 \%$ & $47.92 \%$ & $61.46 \%$ & $76.04 \%$ & $81.25 \%$ \\
\hline
\end{tabular}


We ran a 2 (agent) $\times 2$ (position of the experimenter) $\times 6$ (locations) ANOVA. First, we calculated the percentages of too use (since there are only two demonstratives to use (see, too), the percentage use of see is the complement).

The assumption of sphericity was violated in the analysis of location, and in the interaction between position $\times$ location and agent $\times$ position $\times$ location. We used the Greenhouse-Geisser correction for those analyses. There was a strong main effect of location $F(2.290,70.996)=59.588, p<0.001, \eta p^{2}=0.658$, showing a strong contrast between use of too when the object was within reach (approximately $11 \%$ at $25 \mathrm{~cm}$ and $50 \mathrm{~cm}$ distance) and extrapersonal space (from approximately $50 \%$ at $150 \mathrm{~cm}$ up to $80 \%$ at $275 \mathrm{~cm}$ and $300 \mathrm{~cm}$ ) (Figure 5). There were no other main effects: agent, $p=0.091, \eta p^{2}=0.09$, position, $p=0.164, \eta p^{2}=0.061$ and no other interactions (all $p$-values were $>0.235$ ).

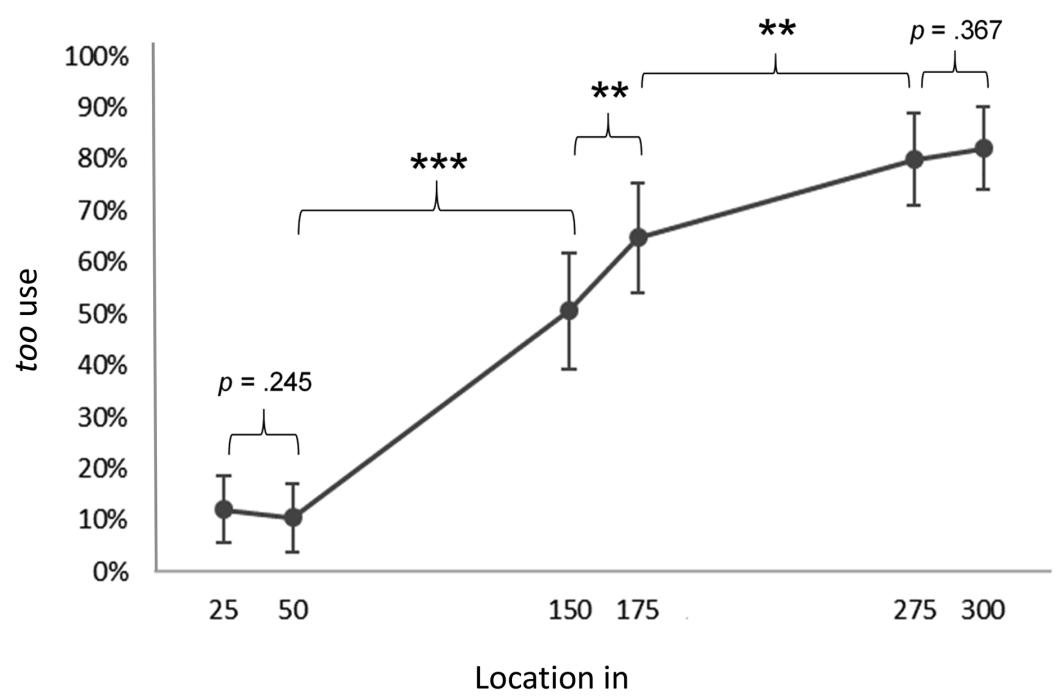

Figure 5: Percentages of too-use at the different locations in $\mathrm{cm}$ (respectively $\mathrm{Y}$-axis and $\mathrm{X}$-axis). Error bars are $95 \%$ confidence intervals. LSD comparisons: ${ }^{\star} p<0.05,{ }^{\star \star} p<0.01$,

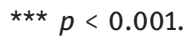

\subsubsection{Discussion}

The results show that the choice of the Common Estonian demonstratives is strongly influenced by distance, corroborating previous findings (Reile 2016); see is the proximal and too the distal demonstrative - the farther away, the more likely the use of too. There is a steep increase in too use between peripersonal 
space (the 25 and $50 \mathrm{~cm}$ locations), with around 10\% too-use, medium far extrapersonal space (at 150 and $175 \mathrm{~cm}$ ) with over $60 \%$ too-use and the farthest extrapersonal locations (275 and $300 \mathrm{~cm}$ ) with around $80 \%$ too-use. However, as too use keeps increasing after the peripersonal/extrapersonal contrast, Common Estonian might be sensitive to a more fine-grained distance contrast. The present study also manipulated participants' relation to the object and position of the addressee, and we found no effects of these parameters on demonstrative use, which suggests that distance is a strong factor differentiating the two adnominal demonstrative pronouns in the spatial context.

While there may be other interactional factors affecting choice of demonstratives in Common Estonian that we have not tested, the absence of an effect of addressee position, and critically the absence of an interaction between addressee position and distance, nevertheless fails to support the 'sociocentric' account of demonstratives. Recall that Peeters et al. $(2015,2016)$ predicted that the proximal term alone should be used in face-to-face settings (Peeters et al. 2015, Peeters et al. 2016). This was not the pattern we found, with the predominant use of the distal demonstrative (rather than the proximal) in locations out of reach of the participant even when the addressee was facing and sitting opposite the participant. The lack of sensitivity to the influence of interactional parameters tested is also in accordance with the overall principles of Estonian demonstrative use in other referential contexts. While see has multiple functions in endophoric reference, too is used only in limited situations. For example, Hint et al. (2017) have shown that the demonstrative pronoun too is almost never used as a determiner in experimentally elicited narratives whereas see is used frequently to differentiate between two highly accessible animate referents. In addition, see has multiple functions in interactions, such as marking hesitation (Keevallik 2010) and serves as a tool for emphasis (Sahkai 2003). Moreover, see can refer to any referent that is cognitively activated (Pajusalu 2009). The main function of too, however, is to refer to past-time events and second characters in literary narratives (Pajusalu 2006). It is more than plausible, therefore, that too has limited use in endophoric as well as exophoric reference leaving only distance to be the influential factor of demonstrative pronoun choice in spatial reference where the goal of the speakers is to identify and locate the referent. Next we consider the results for Võro - a 3-term system.

\subsection{Võro experiment: Demonstratives in a 3-term system}

For some of the combinations of locations and conditions, one of the demonstratives was never used (for example, sjoo was never used when the object was 
located in $275 \mathrm{~cm}$ distance and the experimenter was seated opposite the participant, Table 2) and not all of the participants used the term taa (this demonstrative was used by 19 participants). So we decided to run separate analyses for each demonstrative. Table 2 shows that tuu was used mainly to refer to objects in extrapersonal space, and sjoo in peripersonal space. The use of taa is less frequent overall, and its pattern of use is less clear.

Table 2: Frequency of use of demonstratives by agent, position and location.

\begin{tabular}{|c|c|c|c|c|c|c|c|c|}
\hline Agent & Position & Demonstrative & $25 \mathrm{~cm}$ & $50 \mathrm{~cm}$ & $150 \mathrm{~cm}$ & $175 \mathrm{~cm}$ & $275 \mathrm{~cm}$ & $300 \mathrm{~cm}$ \\
\hline \multirow[t]{6}{*}{ Experimenter } & Next to & sjoo & $75.31 \%$ & $60.49 \%$ & $22.22 \%$ & $8.64 \%$ & $1.23 \%$ & $1.23 \%$ \\
\hline & & taa & $20.99 \%$ & $29.63 \%$ & $37.04 \%$ & $14.81 \%$ & $3.70 \%$ & $4.94 \%$ \\
\hline & & tuu & $3.70 \%$ & $9.88 \%$ & $40.74 \%$ & $76.54 \%$ & $95.06 \%$ & $93.83 \%$ \\
\hline & Opposite & sjoo & $86.42 \%$ & $71.60 \%$ & $29.63 \%$ & $11.11 \%$ & $0.00 \%$ & $2.47 \%$ \\
\hline & & taa & $12.35 \%$ & $23.46 \%$ & $44.44 \%$ & $18.52 \%$ & $7.41 \%$ & $2.47 \%$ \\
\hline & & tuu & $1.23 \%$ & $4.94 \%$ & $25.93 \%$ & $70.37 \%$ & $92.59 \%$ & $95.06 \%$ \\
\hline \multirow[t]{6}{*}{ Participant } & Next to & sjoo & $83.95 \%$ & $64.20 \%$ & $32.10 \%$ & $7.41 \%$ & $6.17 \%$ & $1.23 \%$ \\
\hline & & taa & $16.05 \%$ & $25.93 \%$ & $29.63 \%$ & $20.99 \%$ & $6.17 \%$ & $3.70 \%$ \\
\hline & & tuu & $0.00 \%$ & $9.88 \%$ & $38.27 \%$ & $71.60 \%$ & $87.65 \%$ & $95.06 \%$ \\
\hline & Opposite & sjoo & $86.42 \%$ & $79.01 \%$ & $32.10 \%$ & $12.35 \%$ & $4.94 \%$ & $3.70 \%$ \\
\hline & & taa & $12.35 \%$ & $17.28 \%$ & $43.21 \%$ & $27.16 \%$ & $6.17 \%$ & $1.23 \%$ \\
\hline & & tuu & $1.23 \%$ & $3.70 \%$ & $24.69 \%$ & $60.49 \%$ & $88.89 \%$ & $95.06 \%$ \\
\hline
\end{tabular}

\subsubsection{Results of analysis 1: sjoo}

We ran a 2 (agent) $\times 2$ (position of the experimenter) $\times 6$ (locations) ANOVA. Sjoo was seldom used in the farthest locations, and was not used at all at the $275 \mathrm{~cm}$ distance when the experimenter placed the object and was seated opposite the participant (Table 2). ${ }^{5}$ The assumption of sphericity was violated in the analysis of location and the interactions of agent $\times$ location, position $\times$ location, and agent $\times$ position $\times$ location. We used the Greenhouse-Geisser correction for these analyses.

There was a main effect of agent, $F(1,26)=7.298, p=0.012, \eta p^{2}=0.219$, showing that sjoo use is higher when the participant placed the object $(M=34.5 \%$, $S E=3 \%, 95 \%$ CI $[28.3 \%, 40.6 \%])$ compared to when the experimenter placed it

5 This is a violation of the assumption of homogeneity of variance. However, since the sample sizes are equal (we test the exact same participants across conditions), an ANOVA is fairly robust against this violation (Field 2009). 
$(M=30.9 \%, S E=2.8 \%, 95 \%$ CI $[25.1 \%, 36.7 \%])$. An effect of location was also present, $F(2.671,69.443)=87.077, p<0.001, \eta p^{2}=0.770$; sjoo was used significantly less frequently the farther away the object was placed (Figure 6), and all locations were significantly different from each other (apart from the locations at $275 \mathrm{~cm}$ and $300 \mathrm{~cm})$. There was no effect of position $\left(p=0.095, \eta p^{2}=0.104\right)$ and there were also no interactions (all $p$-values $>0.143$ ).

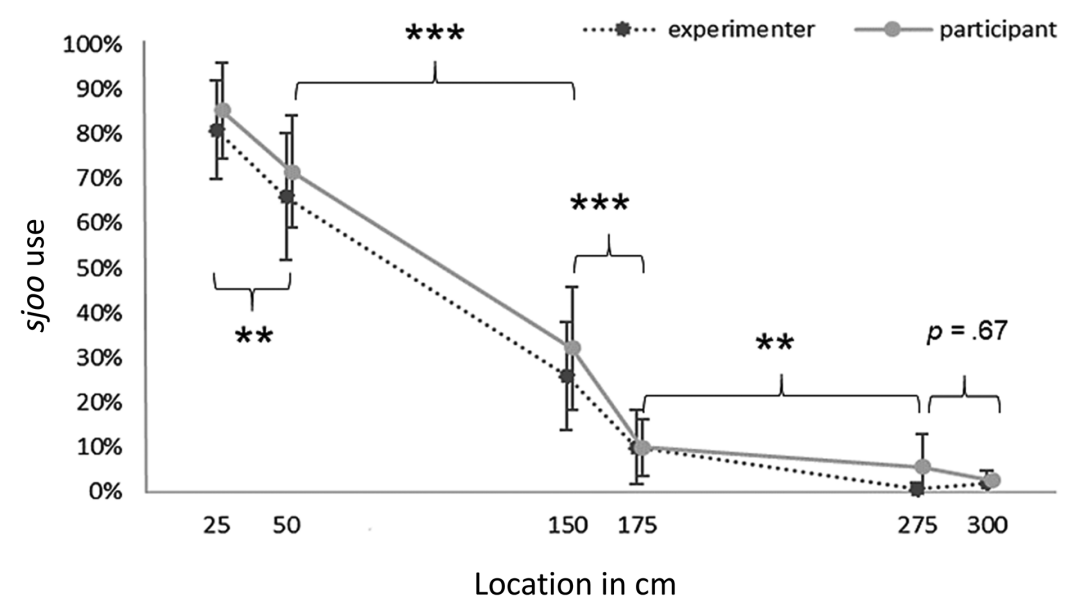

Figure 6: The percentage of sjoo use by distance and agent. Sjoo use declines strongly by distance (LSD tests show differences between locations: ${ }^{*} p<0.05,{ }^{\star \star} p<0.01$, ${ }^{\star \star *} p<0.001$ ). Error bars are $95 \%$ confidence intervals.

\subsubsection{Results of analysis 2: taa}

We ran a 2 (agent) $\times 2$ (position of the experimenter) $\times 6$ (locations) ANOVA. There was a lack in variance in some cells of the design at $275 \mathrm{~cm}$ and $300 \mathrm{~cm}$. The assumption of sphericity was violated in the analysis of location, and the interactions of agent $\times$ location, position $\times$ location, and agent $\times$ position $\times$ location; we used the Greenhouse-Geisser correction for these analyses.

There was a main effect of location, $F(2.695,70.075)=8.468, p<0.001$, $\eta p^{2}=0.246$, in which there were significant differences in taa use between $50 \mathrm{~cm}$ and $150 \mathrm{~cm}(p=0.010), 150 \mathrm{~cm}$ and $175 \mathrm{~cm}(p=0.013)$, and between $175 \mathrm{~cm}$ and $275 \mathrm{~cm}(p=0.019)$. There were no main effects of agent $(p=0.594$, $\left.\eta p^{2}=0.011\right)$ or position $\left(p=0.940, \eta p^{2}<0.001\right)$.

There were two marginally significant interactions with location, showing smaller effect sizes. The first was between agent $\times$ location, $F(2.923,75.999)=2.726$, 
$p=0.051, \eta p^{2}=0.095$, in which the use of taa was higher when the experimenter placed the object up to $150 \mathrm{~cm}$ from the participant, but lower when the experimenter placed at the $175 \mathrm{~cm}$ location (Figure 7, panel A). Second, there was an interaction between position $\times$ location, $F(3.373,87.695)=2.609, \quad p=0.050$, $\eta p^{2}=0.091$, in which taa use is higher at the two close locations when the experimenter sat next to the participant, compared to objects placed at $150 \mathrm{~cm}$ and $175 \mathrm{~cm}$ (Figure 7, panel B). None of the other interactions were significant (all $p>0.312)$.

A
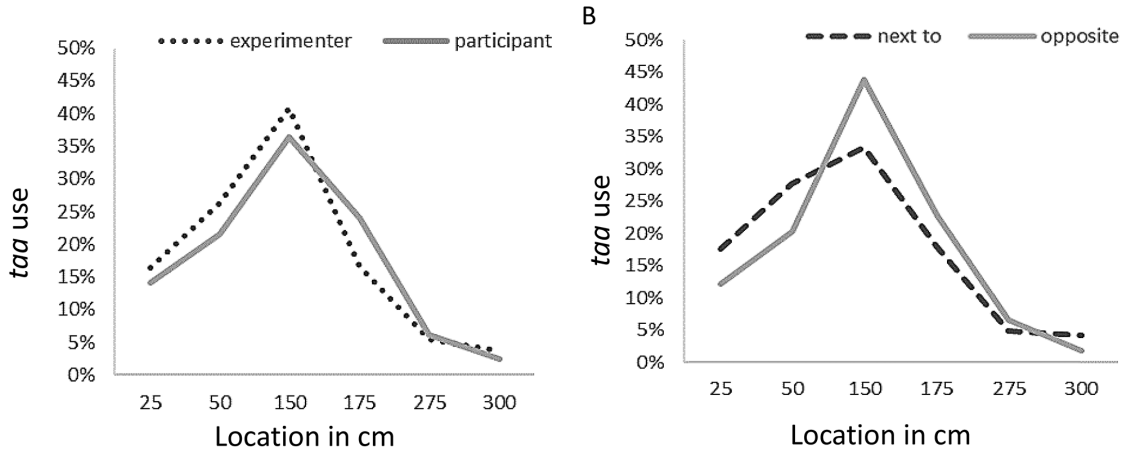

Figure 7: The marginal interactions with location in the analysis of taa. Panel A shows the interaction between agent and location, Panel B presents the interaction between position and location.

\subsubsection{Results of analysis 3: tuu}

We ran a 2 (agent) $\times 2$ (position of the experimenter) $\times 6$ (locations) ANOVA. Tuu was seldom used in the nearest two locations, and never used in the nearest location when the participants were seated next to one another and the participant placed the object, but as this is a within-participants design, the ANOVA is robust against these violations of homogeneity of variance.

The assumption of sphericity was violated in the analysis of location and the interactions of agent $\times$ location, position $\times$ location, and agent $\times$ position $\times$ location, so we used the Greenhouse-Geisser correction for these analyses.

There was a main effect of location, $F(2.830,73.580)=138.864, p<0.001$, $\eta p^{2}=0.842$, in which tuu was used more frequently as the object was placed farther away (Figure 8). There was also a main effect of position, $F(1,26)=4.956, p=0.035$, $\eta p^{2}=0.161$, in which tuu was used more frequently when experimenter and participant were seated side-by-side $(\mathrm{M}=51.9 \%, \mathrm{SE}=2.9 \%, 95 \%$ CI $[46 \%, 57.7 \%])$ 
compared to when they sat opposite one another $(M=47 \%, S E=2.1 \%, 95 \%$ CI $[42.7 \%, 51.3 \%])$. There was no effect of agent $\left(p=0.088, \eta p^{2}=0.108\right)$. And there were no interactions (all $p$-values were $>0.069){ }^{6}$

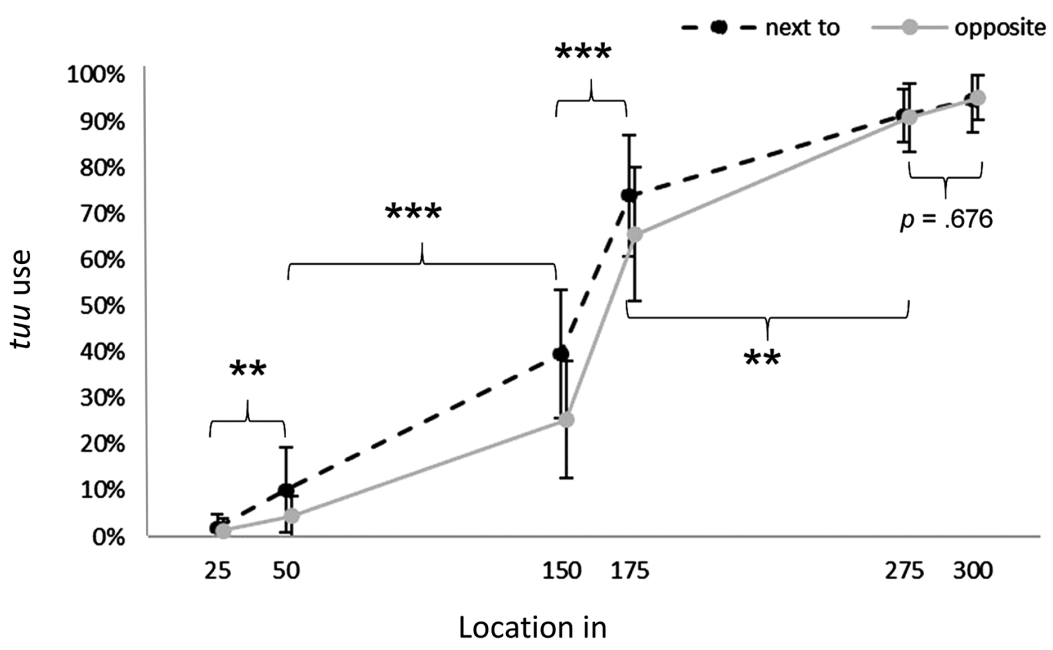

Figure 8: The percentage of tuu use by position and location. The use of tuu strongly increases as the object was placed farther away (LSD tests indicate difference between locations, $\left.{ }^{*} p<0.05,{ }^{* *} p<0.01,{ }^{* \star *} p<0.001\right)$. Error bars are $95 \%$ confidence intervals.

\subsubsection{Discussion}

It has been suggested that some three-term demonstrative systems have speakerand addressee-anchored terms, such as in Japanese (Diessel 2013). In these languages, one term is reported to mark a location near the speaker, one to mark a location near the hearer, and the last to mark a location far from both hearer and speaker. For Võro, there has been a lack of consensus whether this language has speaker- and addressee-anchored (Pajusalu 1998) or speakeranchored (Keem and Käsi 2002) terms. The design of the present experiment was able to test this in Võro.

6 We ran additional exploratory analysis to test whether there were gender effects in Võro, but found none, apart from a four-way interaction between agent $\times$ position $\times$ location $\times$ gender, $F(5,125)=2.858, p=0.03, \eta p^{2}=0.103$, in the tuu analysis. However, the main effects in both the male and female participants were consistent with the main analysis. 
Results of the Võro demonstrative system analysis show that distance has a strong influence on all three terms: sjoo indicates the closest referent, tuu the farthest, taa is used in the middle location. Additionally, we found a main effect of agent on sjoo use, and a main effect of position of the addressee (presented by the experimenter) on tuu use. Both of these parameters have an effect on taa use but only in specific locations. In addition, taa proves to be an infrequently used demonstrative throughout the experiment. The pattern of results for taa show that this term is used primarily in the middle distances although there were marginally significant interactions with the interactional parameters. The data therefore suggests that distance has the strongest influence on demonstrative production, but effects of interactional parameters cannot be ruled out based on our data. However, as with Common Estonian, we again do not find support for the 'sociocentric' account (Peeters et al. 2015, 2016); the proximal term was not exclusively used when the addressee was seated opposite and facing the participant. Furthermore, it should be noted that taa was used rather infrequently in our experiment. This is consistent with the suggestion that taa is losing its addressee-anchorage and spatial contrastive function (Pajusalu 2015) and that the system is disintegrating into several systems in Võro idiolects (Tammekänd 2015). Taa might therefore be exemplary for the changes taking place in the Võro demonstrative pronoun system.

\section{General discussion}

In this study, we compared the use of adnominal demonstrative pronouns in two very closely related languages: Common Estonian with a two-term demonstrative pronoun system and Vorro with a three-term system. We tested the effect of distance and two interactional space parameters, the person who placed the object in question and the position of the experimenter in an experimental setting. The two latter parameters tested present the dynamic aspects of an interactional setting that can occur during a conversation - interlocutors change their location during interaction and manipulate the objects indicated. Moreover, the manipulation of addressee position provides a direct test of the 'sociocentric' account of demonstratives proposed by Peeters et al. $(2015,2016)$, in which the proximal term is assumed to be preferred during face-to-face interaction irrespective of the distance of the referent from the participant (in line with Jungbluth 2003). The findings show that distance exerts a strong influence on demonstrative use in both languages, with influence of the interactional parameters in Võro. However, across both languages, the pattern of the data does not support the sociocentric account. 
There has been a debate over the primary factors that influence the use of spatial demonstrative pronouns. There is evidence to support the importance of egocentric distance (e. g. Diessel 1999, Diessel 2013; Dixon 2003; Tóth et al. 2014; Coventry et al. 2008, Coventry et al. 2014) as well as interactional factors (Hanks 1992, Hanks 2011; Laury 1997; Enfield 2003; Etelämäki 2009; Jarbou 2010; Coventry et al. 2014; Peeters et al. 2015). The findings of our study support both approaches but show that distance is more influential in explicitly spatial situations than the interactional parameters. While the use of adnominal demonstrative pronouns in Võro is also influenced by the interactional parameters, they had weaker influence than distance and slightly mediated the effects of distance rather than changing the overall pattern of use of the terms available. Furthermore, specific terms seem to be influenced by specific parameters. Sjoo was influenced by agent (the one who places the object), but not by position of the experimenter; while tuu was influenced by position of the experimenter, but not by agent. Moreover, the middle term - taa seemed affected by both position of the experimenter and agent at the middle locations. So when the impact of distance is weakest with a third term in Võro, that term appears to be more susceptible to the influence of interactional factors.

The strong effect of distance supports the view that egocentric distance is important for demonstrative systems. The present data coincides with Diessel's (1999) claim that the distinction between near and far distance is the basis for demonstrative contrasts in two-term systems and is also consistent with the empirical evidence supporting a link between perceptual space and demonstrative use (Coventry et al. 2008, Coventry et al. 2014). The use of the Common Estonian demonstrative too and Võro tuu increased drastically when it was used for objects situated in extrapersonal space. Therefore, the influence of peripersonal/extrapersonal space distinction in demonstrative use is evident also in Common Estonian and Võro as has been argued for English, a two-term language, and Spanish, a three-term language, using the same experimental design (Coventry et al. 2008, Coventry et al. 2014). We note that no effects of the experimenter's position or agent were found for Common Estonian, which deviates from results found in English, where effects of agent has been reported previously (Coventry et al. 2008), but they were present in Võro. This might suggest that the strength of interactional parameters is more language-specific than the influence of distance.

From an interactional perspective, it has been suggested that demonstratives might not be egocentric distance-based, but instead might rely on the interactional setting between speaker and hearer, such as face-to-face reciprocal vision (Hanks 2011). In that respect, the seating position of the experimenter is a reasonable test of the importance of the dyadic setting. Jungbluth (2003) has emphasised that different positions of the interlocutors have a different effect on 
demonstrative use, and building on Jungbluth's proposals, Peeters et al.'s (2015) 'sociocentric' approach to demonstratives assumes that the proximal term is used irrespective of egocentric distance in a face-to-face setting. Our results were not consistent with this account; in both languages the proximal term was not very often used when the object was out of reach of the participant in the face-to-face condition. Moreover, contrary to Spanish, in Võro the distal demonstrative pronoun was affected by the experimenter's position rather than the proximal and mostly in the middle locations. The middle distance of our experimental setting fell into extrapersonal space of the participant and the experimenter, and the effect of the position of the experimenter was weaker than the effect of distance. Although it might be that the dyadic setting caused participants to use tuu less since the objects were located in the shared interational space and participants were engaged in a joint activity with the experimenter, this effect is not strong enough to change the pattern of demonstrative use (for participants to use only proximal demonstratives). Consequently, we can conclude that when the context of demonstrative use is explicitly spatial and the conversational dyad covers the extrapersonal space of both interlocutors, its effect is limited and weaker than the effect of distance.

Another account that has been proposed for an explanation of demonstrative use is the accessibility of the referent, either spatial, perceptual or cognitive (Hanks 2011). According to Laury (1997) the use of Finnish demonstrative pronouns depends on the social and cognitive accessibility of the referents for the interlocutors. In the current study, the manipulation of the participants' relation to the object referred to provided a good means for testing the influence of accessibility (other than spatial or perceptual). The results show that there is an effect of agent on sjoo use because it was used more often when the participant placed the object compared to the experimenter. This suggest that the notion of interlocutors' spheres may have an effect also on the use of Vorro demonstratives, where sjoo indicates that the object referred to is included in the speaker's sphere rather than that of the hearer's.

Although research on demonstratives has gained extensive interest in linguistic and psychological research for the past few years, there is an important factor that has been overlooked in demonstrative studies so far: the influence of language contact. Due to language contact there could be changes that are subtle and hard to detect but which may be responsible for changing demonstrative pronoun systems. Comparing the results of the two languages, it is evident that the level of contrast strength between proximal and distal demonstratives is stronger in Võro. This seems to indicate that in Estonian proximal see is beginning to lose its spatial marking in the two-term system due to the constant pressure of the one-term system, where see is used distance-neutrally 
(Reile 2015, Reile 2016). Also, the infrequent use of taa and the interaction between distance and interactional parameters in the Võro three-term system suggest strong influence of the Estonian two-term system, where there is no suitable counterpart for taa. Furthermore, our findings on the use of taa also corroborate the proposition that Võro has lost its addressee-anchored use of taa (Pajusalu 2015), which indicates the influence of Estonian on Võro.

The memory game procedure combines a high level of control over the influence of distance and conversational setting on demonstrative use, with a high degree of ecological validity (Gudde et al. 2018). For example, by only presenting a single referent each trial, we avoid contrastive use to affect demonstrative production. Furthermore, participants were unaware that the study tested their language production (confirmed upon debrief). Therefore, participants' language use is as natural as possible even though the lab setting does not fully imitate natural conversation. Moreover, the effects of both interactional parameters we manipulated have been uncovered also in other languages using the same method. The agent manipulation has already been found in both English and Spanish (Coventry et al. 2008, 2014), and Gudde and Coventry (2017) show that there are effects of the position of the conspecific in Japanese (and that the effects were weaker in English than in Japanese). Therefore, these parameters influence the use of demonstratives, but the strength of influence might depend on whether or not a contrast is explicitly marked in a language. As for the influence of distance, this parameter seems to be present also for different languages and across experimental designs (e.g. Bonfiglioli et al. 2009; Tóth et al. 2014; Judžentytė 2017).

\section{Conclusions}

There is a clear indication that distance of the referent is an influential parameter on demonstrative choice whereas interactional parameters have no or weaker influence in the two languages tested in this study. However, the effects of position of the interlocutor and agent in Võro show that dynamic elements of a speech situation should not be overlooked. Demonstrative use seems to be a function of different parameters. While distance shows robust effects across languages, the strength of the effects of other parameters might be mediated by whether a language explicitly marks a contrast of a given parameter. Beside these factors, language contact might have an influence on demonstrative systems as well. Thus, it is important to look at both distance and interactional parameters of reference in experimental studies on demonstratives and also to consider sociolinguistic aspects of demonstrative research. 
Acknowledgements: This work was partly supported by the European Union's Horizon 2020 research and innovation programme under the Marie SkłodowskaCurie Actions [grant agreement No. 676063] (grant awarded to the last author), The Estonian Research Council [PUT701], and by the European Union through the European Regional Development Fund [Centre of Excellence in Estonian Studies].

\section{References}

Anderson, Stephen R. \& Ed L. Keenan. 1985. Deixis. In Timothy Shopen (ed.), Language typology and syntactic description: Grammatical categories and the lexicon, vol. 3, 259-308. Cambridge: Cambridge University Press.

Berti, Anna \& Francesca Frassinetti. 2000. When far becomes near: Remappings of space by tool use. Journal of Cognitive Neuroscience 12(3). 415-420.

Bohnemeyer, Jürgen. 2012. Yucatec demonstratives in interaction: Spontaneous vs. elicited data. In A. C. Schalley (ed.), Practical theories and empirical practice, 99-128. Amsterdam: John Benjamins.

Bonfiglioli, Claudia, Chiara Finocchiaro, Benno Gesierich, Francesco Rositani \& Massimo Vescovi. 2009. A kinematic approach to the conceptual representations of this and that. Cognition 111(2). 270-274. doi:10.1016/j.cognition.2009.01.006.

Caldano, Michela \& Kenny R. Coventry. 2019. Spatial demonstratives and perception space: To reach or not to reach? Cognition 191. 103989. doi:10.1016/j.cognition.2019.06.001.

Coventry, Kenny R., Debra Griffiths \& Colin J. Hamilton. 2014. Spatial demonstratives and perceptual space: Describing and remembering object location. Cognitive Psychology 69. 46-70. doi:10.1016/j.cogpsych.2013.12.001.

Coventry, Kenny R., Berenice Valdés, Alejandro Castillo \& Pedro Guijarro-Fuentes. 2008. Language within your reach: Near-far perceptual space and spatial demonstratives. Cognition 108(3). 889-895. doi:10.1016/j.cognition.2008.06.010.

Dialectological dictionary of Estonian. http://www.eki.ee/dict/vms/index.html.en (accessed 26 June 2019).

Diessel, Holger. 1999. Demonstratives: Form, function and grammaticalization (Typological Studies in Language 42). Amsterdam: Benjamins.

Diessel, Holger. 2006. Demonstratives, joint attention, and the emergence of grammar. Cognitive Linguistics 17(4). 463-489. doi:10.1515/COG.2006.015.

Diessel, Holger. 2013. Distance contrasts in demonstratives. The World Atlas of Language Structures Online. http://wals.info/chapter/41.

Diessel, Holger. 2014. Demonstratives, frames of reference and semantic universals of space. Language and Linguistics Compass 8(3). 116-132.

Dixon, Robert M. W. 2003. Demonstratives: A cross-linguistic typology. Studies in Language 27(1). 61-112.

Eesti Keeleseadus (23.02.2011) [Estonian Language Act]. https://www.riigiteataja.ee/akt/ 118032011001 (accessed 20 February 2019). 
Enfield, Nicholas J. 2003. Demonstratives in space and interaction: Data from Lao speakers and implications for semantic analysis. Language 79(1). 82-117.

Etelämäki, Marja. 2009. The Finnish demonstrative pronouns in light of interaction. Journal of Pragmatics 41(1). 25-46.

Evans, Nicholas \& Stephen C. Levinson. 2009. The myth of language universals: Language diversity and its importance for cognitive science. Behavioral and Brain Sciences 32(5). 429-492.

Field, Andy. 2009. Discovering statistics using SPSS. London: SAGE.

Fillmore, Charles J. 1997. Lectures on deixis. Stanford: CSLI Publications.

Gudde, Harmen B. \& Kenny R. Coventry. 2017. Language and spatial memory in Japanese and English. In Glenn Gunzelmann, Andrew Howes, Thora Tenbrink \& Eddy Davelaar (eds.), Proceedings of the 39th Annual Conference of the Cognitive Science Society, vol. 451. Austin TX: Cognitive Science Society.

Gudde, Harmen B., Kenny R. Coventry \& Paul E. Engelhardt. 2016. Language and memory for object location. Cognition 153. 99-107.

Gudde, Harmen B., Debra Griffiths \& Kenny R. Coventry. 2018. The (spatial) memory game: Testing the relationship between spatial language, object knowledge, and spatial cognition. Journal of Visualised Experiments 132. 56495.

Halliday, M. A. K. \& Ruqaiya Hasan. 1976. Cohesion in English. London: Longman.

Hanks, William F. 1992. The indexical ground of deictic reference. In Alessandro Duranti \& Charles Goodwin (eds.), Rethinking context: Language as an interactive phenomenon. Cambridge: Cambridge University Press.

Hanks, William F. 2009. Fieldwork on deixis. Journal of Pragmatics 41(1). 10-24. doi:10.1016/j. pragma.2008.09.003.

Hanks, William F. 2011. Deixis and indexicality. In Wolfram Bublitz \& Neal R. Norrick (eds.), Foundations of pragmatics, 315-346. Berlin: De Gruyter Mouton.

Himmelmann, Nikolaus P. 1996. Demonstratives in narrative discourse. In Barbara Fox (ed.), Studies in Anaphora, 205-254. Amsterdam: Benjamins.

Hint, Helen, Tiina Nahkola \& Renate Pajusalu. 2017. With or without articles? A comparison of article-like determiners in Estonian and Finnish. Lähivõrdlusi. Lähivertailuja 27. 65-106.

Jääts, Indrek. 2015. Count us! Ethnic activism in South-Eastern Estonia, and the census of 2011. Journal of Baltic Studies 46(2). 243-260. doi:10.1080/01629778.2014.954761.

Jarbou, Samir Omar. 2010. Accessibility vs. physical proximity: An analysis of exophoric demonstrative practice in spoken Jordanian Arabic. Journal of Pragmatics 42(11). 3078-3097. doi:10.1016/j.pragma.2010.04.014.

Judžentytè, Gintarè. 2017. Spatial deixis in Lithuanian: Demonstrative pronouns. Language: Meaning and Form 8. 173-193.

Jungbluth, Konstanze. 2003. Deictics in the conversational dyad. In Friedrich Lenz (ed.), Deictic conceptualisation of space, time and person, 13-40. Amsterdam: Benjamins.

Kallio, Petri. 2007. Kantasuomen konsonanttihostoriaa [On the history of Proto-Finnic consonants]. In Jussi Ylikoski \& Ante Aikio (eds.), Sámit, sánit, sátnehámit: Riepmočála Pekka Sammallahtii miessemánu 21. beaivve 2007 [The Sami people, words and word-forms: Festschrift for Pekka Sammallahti on 21 May 2007] (Mémoires de la Société FinnoOugrienne 253), 229-249. Helsinki: Société Finno-Ougrienne.

Keem, Hella \& Inge Käsi. 2002. Eesti murded VI. Võru murde tekstid [Estonian dialects VI. Texts of Võro dialects]. Tallinn: Eesti Keele Instituut. 
Keevallik, Leelo. 2010. The interactional profile of a placeholder: the Estonian demonstrative see. In Nino Amiridze, Boyd H. Davis \& Margaret Maclagan (eds.), Fillers, pauses, and placeholders (Typological Studies in Language 93), 139-172. Amsterdam: John Benjamins.

Koreinik, Kadri. 2013. The Võro language in Estonia: ELDIA case-specific report (Studies in European Language Diversity 23). Mainz: ELDIA.

Küntay, Aylin C. \& Asli Özyürek. 2006. Learning to use demonstratives in conversation: What do language specific strategies in Turkish reveal? Journal of Child Language 33(2). 303-320. doi:10.1017/S0305000906007380.

Larjavaara, Matti. 1986. Demonstratiivit ja kielen kehitys [The development of the Finnic demonstrative system]. Virittäjä 90(3). 306-312.

Larjavaara, Matti. 1990. Suomen deiksis [Deixis in Finnish]. Helsinki: Suomalaisen Kirjallisuuden Seura.

Larjavaara, Matti. 2007. Pragmasemantiikka [Pragmasemantics]. Helsinki: Suomalaisen Kirjallisuuden Seura.

Laury, Ritva. 1997. Demonstratives in interaction: The emergence of a definite article in Finnish. Amsterdam: Benjamins.

Levinson, Stephen C. 2006. Deixis. In Laurence R. Horn \& Gregory Ward (eds.), The Handbook of pragmatics, 2nd edn, 97-121. Oxford: Blackwell.

Levinson, Stephen C. 2018. Demonstratives - patterns in diversity. In Stephen C. Levinson, Sarah Cutfield, Michael Dunn, Nick Enfield \& Sérgio Meira (eds.), Demonstratives in crosslinguistic perspective (Language Culture and Cognition 14), 1-35. Cambridge: Cambridge University Press.

Lyons, John. 1977. Semantics. vol. 2. Cambridge: Cambridge University Press.

Pajusalu, Karl. 1997. Keskse perifeeria mõjust eesti keele tekkeloos [The influence of the central periphery on the evolution of Estonian]. In Mati Erelt, Meeli Sedrik \& Ellen Uuspõld (eds.), Pühendusteos Huno Rätsepale (Tartu Ülikooli Eesti Keele õppetooli Toimetised 7), 167-183. Tartu: Tartu Ülikool.

Pajusalu, Renate. 2006. Death of a demonstrative: person and time. The case of Estonian too. Linguistica Uralica 42(4). 241-253.

Pajusalu, Karl, Tiit Hennoste, Ellen Niit, Peeter Päll \& Jüri Viikberg. 2009. Eesti murded ja kohanimed [Estonian dialects and place names], 2nd edn. Tallinn: Eesti Keele Sihtasutus.

Pajusalu, Karl, Tiit Hennoste, Ellen Niit, Peeter Päll \& Jüri Viikberg. 2018. Eesti murded ja kohanimed [Estonian dialects and place names], 3rd edn. Tallinn: Eesti Keele Sihtasutus. http://www.emakeeleselts.ee/digiraamatud/Eesti-murded-ja-kohanimed_kolmas-trykk_ 2018.pdf.

Pajusalu, Renate. 1997a. Eesti pronoomenid I/1. Ühiskeele see, too ja tema/ta [Estonian pronouns I/1: Common Estonian see, too and tema/ta]. Keel ja Kirjandus 1. 24-30.

Pajusalu, Renate. 1997b. Is there an article in (Spoken) Estonian? Estonian Typological Studies 2(8). 146-177.

Pajusalu, Renate. 1998. Eesti pronoomenid II. Võru sjoo, taa, tuu ja timä [Estonian pronouns II: Võru sjoo, taa, tuu and timä]. Keel ja Kirjandus 3. 159-172.

Pajusalu, Renate. 2009. Pronouns and reference in Estonian. Sprachtypologie und Universalienforschung 62(1-2). 122-139.

Pajusalu, Renate. 2015. Võro demonstratives: Changing or disappearing? Journal of Estonian and Finno-Ugric Linguistics 6(2). 167-190.

Pajusalu, Renate. 2017. Viiteseosed [Referential linkage]. In Mati Erelt \& Helle Metslang (eds.), Eesti keele süntaks [Estonian syntax], 566-589. Tartu: University of Tartu Press. 
Peeters, David, Peter Hagoort \& Aslı Özyürek. 2015. Electrophysiological evidence for the role of shared space in online comprehension of spatial demonstratives. Cognition 136. 64-84. doi:10.1016/j.cognition.2014.10.010.

Peeters, David \& Aslı Özyürek. 2016. This and that revisited: A social and multimodal approach to spatial demonstratives. Frontiers in Psychology 7. 2014-2017.

Pellegrino, Giuseppe di \& Elisabetta Làdavas. 2015. Peripersonal space in the brain. Neuropsychologia 66. 126-133. doi:10.1016/j.neuropsychologia.2014.11.011.

Piwek, Paul, Robbert-Jan Beun \& Anita Cremers. 2008. "Proximal" and "distal" in language and cognition: Evidence from deictic demonstratives in Dutch. Journal of Pragmatics 40(4). 694-718. doi:10.1016/j.pragma.2007.05.001.

Reile, Maria. 2015. Space and demonstratives: An experiment with Estonian exophoric demonstratives. Journal of Estonian and Finno-Ugric Linguistics 6(2). 137-165. doi:10.12697/jeful.2015.6.2.06.

Reile, Maria. 2016. Distance, visual salience and contrast expressed through different demonstrative systems: An experimental study in Estonian. SKY Journal of Linguistics 29. 63-94.

Saareste, Andrus. 1955. Petit atlas des parlers Estoniens. Väike eesti murdeatlas (Skrifter utgivna av Kungl. Gustav Adolfs Akademien 28). Uppsala: Kungl. Gustav Adolfs Akademien.

Sahkai, Heete. 2003. Demonstrative doubling in spoken Estonian. Trames: Journal of the Humanities and Social Sciences 7(2). 120-144.

Sammallahti, Pekka. 1977. Suomalaisten esihistorian kysymyksia [Problems of Finnic prehistory]. Virittäjä 2. 119-136.

Statistics Estonia. 2012. 2011 Population and Housing Census: PCE07: Permanent residents with Estonian as their mother tongue, 31 December 2011 by Ability to speak a dialect and Sex. http://pub.stat.ee/px-web.2001/dialog/statfile1.asp (accessed 1 June 2018).

Strauss, Susan. 2002. This, that, and it in spoken American English: A demonstrative system of gradient focus. Language Sciences 24(2). 131-152.

Talmy, Leonard. 2018. The targeting system of language. Cambridge, MA: The MIT Press.

Tammekänd, Liina. 2015. Demonstratives in Võro and Estonian oral narratives. Journal of Estonian and Finno-Ugric Linguistics 6(2). 191-216.

Tóth, Enikő, Péter Csatár \& Arina Banga. 2014. Exploring Hungarian and Dutch gestural demonstratives. In Ludmila Veselovská \& Markéta Janebová (eds.), Complex visibles out there: Proceedings of the Olomouc Linguistics Colloquium 2014: Language use and linguistic structure (Olomouc Modern Language Series 4), 607-626. Olomouc: Palacký University. 